\title{
Memes, Screens and Broadway Scenes: Popular Culture Representations of Shakespeare's Actors in the Age of Participatory Media
}

\section{Melissa Merchant}

\section{(2) OpenEdition Journals}

Electronic version

URL: https://journals.openedition.org/shakespeare/6234

DOI: $10.4000 /$ shakespeare.6234

ISSN: 2271-6424

Publisher

Société Française Shakespeare

\section{Electronic reference}

Melissa Merchant, "Memes, Screens and Broadway Scenes: Popular Culture Representations of Shakespeare's Actors in the Age of Participatory Media", Actes des congrès de la Société française Shakespeare [Online], 39 | 2021, Online since 19 May 2021, connection on 23 August 2021. URL: http:// journals.openedition.org/shakespeare/6234 ; DOI: https://doi.org/10.4000/shakespeare.6234

This text was automatically generated on 23 August 2021.

(c) SFS 


\title{
Memes, Screens and Broadway Scenes: Popular Culture Representations of Shakespeare's Actors in the Age of Participatory Media
}

\author{
Melissa Merchant
}

In a recent Broadway musical featuring William Shakespeare, the actor and poet tells his audience, through song, "I've got many fans with so many demands / I can hardly go take a piss [...] / Be it theatre freak or the autograph-seeker / They all want a piece of this." ${ }^{1}$ It is notable that representations of Shakespeare in popular culture have multiplied since the rise of participatory media. Shakespeare on Twitter (@Shakespeare) has more than 40,000 followers, while William Shakespeare (@WilliamShakespeareAuthor) on Facebook has over 16 million "likes". Shakespeare memes proliferate on social media sites like Twitter, Facebook and Reddit and there are tens of thousands of Shakespeare fanfictions to be found online. The rise of these types of participatory media platforms has not only given us new outlets for artistic expression, as well as new ways to create and disseminate cultural artefacts, it has also given us new ways of theorising Shakespeare. Today, we can construct our own Shakespeares and disseminate them globally, an example of what Jennifer Holl terms "YouShakespeare," where "online Shakespeares speak not only the poet's verse, but as the poet himself ." In this, we can see Shakespeare as meme. Richard Dawkins originally proposed meme theory in the 1970s, when theorising about how genes replicate; he suggested an alternative to DNA that he called memes, things that behave like a gene in human culture, which can replicate. ${ }^{3}$ According to Mike Ingham, within popular culture and participatory media, "A meme spreads and [...] transforms itself in accordance with the conditions of the new habitat in order to survive." ${ }^{4}$ Shakespeare 
has done this, evolving over the generations since his death and these evolutions are what have kept him relevant to contemporary audiences.

This essay considers fictionalised accounts of Shakespeare and his company of players as depicted in recent popular culture texts, including film, television and theatre. ${ }^{5}$ It explores the existing frameworks and theoretical approaches used when discussing popular culture Shakespeare. Then, drawing on meme theory, it examines three tropes evident in popular culture representations of Shakespeare and his actors that have become common in the age of participatory media. Firstly, Shakespeare was a literary genius, but may also have been a bad actor. Secondly, acting was a profession that others aspired to; this includes amateurs wanting to be professional and women wanting to perform. Finally, males playing female characters was funny; the representations of theatrical transvestism in modern popular culture texts are typically played as comedic. I argue that in these representations, we can see a postmodern need to reshape Shakespeare in our own image, while simultaneously drawing on his cultural capital to either promote or challenge his work as "high" culture.

\section{Theorising Shakespeare 2.0}

3 The idea for this essay began in 2016, after I saw the musical Something Rotten! on Broadway. The story focuses on the fictional characters Nick and Nigel Bottom, actors and writers trying to eke out a living in London's theatres; it also includes Will Shakespeare as the Elizabethan theatre's first real superstar. The story involves Shakespeare disguising himself as the "New York" actor Toby Belch, to infiltrate the Bottom Brother's company of players. Also released in 2016 was the Ben Elton authored television series, Upstart Crow, which was shown on the BBC. Upstart Crow features a middle-aged Shakespeare, one who is already established in London as an actor and who is beginning to write plays. Upstart Crow also includes representations of real Elizabethan actors such as Henry Condell, Richard Burbage and Will Kempe as series regulars. Additionally, Ben Elton has written characters that refer to the Shakespearean canon, such as Bottom and Kate, and each episode follows the plot of one of his plays. As 2016 was the $400^{\text {th }}$ anniversary of Shakespeare's death, it is unsurprising we saw the rise of "Shakespeare's corpse," as termed by Jennifer Moss Waghorn when discussing the proliferation of special events to commemorate "Shakespeare as 'corpse' through presentations of his physical remains including his will, final home and burial site." ${ }^{\text {B }}$ Brian Cummings is more direct in his summation of the events surrounding the $400^{\text {th }}$ anniversary, arguing it has produced "a 'Zombie Shakespeare', a twenty-first century biographical fantasy indicative of commodification rather than literary or creative imagination." It is this "twenty-first century biographical fantasy" that most interested me after seeing both Something Rotten! and Upstart Crow.

4 I began reflecting on fictional representations of Shakespeare and his actors and questioning what similarities could be seen in how they have been written and performed and how Shakespeare, as actor and poet, has been adapted/appropriated in the $21^{\text {st }}$ century. When discussing Shakespearean adaptation, it can be challenging to distinguish between the texts, the man, and his fictional representations. As Ronan Hatfull contends, "Shakespearean adaptation theory often omits to differentiate between whether his name is being used to describe the work, the man or his 
afterlife." ${ }^{\prime 8}$ Much of the research and writing in this area tends to focus on the plays, poems and sonnets; interrogating the ways in which each has been adapted, appropriated, altered, reimagined and reinvented. While there has been some research into fictional representations of Shakespeare the man, this pales in comparison to other fields of Shakespearean adaptation studies. Maurice O'Sullivan, in "Shakespeare's Other Lives," uses the term conscious fictions as a way of separating biographical representations and fictional representations of shakespeare. ${ }^{9}$ I have adopted O'Sullivan's term, conscious fictions, as the texts used in this analysis are fictionalised accounts of Shakespeare and his actors. The term is also used to draw a clear distinction between representations of the man as actor/poet in popular culture texts and his plays.

5 When thinking about recent representations of Shakespeare and his actors, the 1998 film Shakespeare in Love was the first that came to mind. The film tells the story of a Shakespeare who is suffering from writer's block. He meets Viola De Lesseps, who disguises herself as a man and auditions for Shakespeare's next play, Romeo and Ethel the Pirate's Daughter. They fall in love and their romance forms the basis of Romeo and Juliet. Within the film, we see Shakespeare as an actor, as well as both Henslowe and Burbage's companies of players. Interspersed among fictional characters are representations of real Elizabethan actors: Richard Burbage, Will Kempe, Henry Condell and Ned Alleyn. Also featuring Burbage and Kempe as characters was the 2007 Doctor Who episode "The Shakespeare Code". The episode showed the Doctor taking his new companion Martha on a trip to Elizabethan London. While there, they meet William Shakespeare and ruin a plot by alien witches to use Shakespeare's genius to release the rest of their race at the end of a production of Love's Labour's Won. Patterns began to emerge through these conscious fictions of Shakespeare the actor/poet, as well as his company of players and the theatres of Elizabethan London. Shakespeare is typically shown as a troubled genius, writing alone and without the help of his fellow actors. Examples of Shakespeare as a lone writer bringing completed pages to his actors are included in Shakespeare in Love and Doctor Who "The Shakespeare Code". This depiction is also evident in Upstart Crow, although the sitcom does show him workshopping his scripts with his friends and family. The first episode, "Star Crossed Lovers," opens with Shakespeare at home with his family, asking his daughter to read Juliet as he wanted to hear his heroine in the voice of a teenage girl, before "a middle-aged man with two half coconuts down his bodice gets hold of it." ${ }^{10}$ However, in these scenes he is looking for agreement, rather than genuine suggestions, as evidenced by him ignoring their ideas. Even Something Rotten! shows a fame-hungry Shakespeare shut in his room, trying to do "something as good as the last thing I did / that was already great." ${ }^{11}$ Kelly Jones maintains that focusing on Shakespeare as a writing genius, creating masterpieces on his own, diminishes the importance of the players with which he worked. ${ }^{12}$ It is unlikely Shakespeare would have written his plays entirely on his own, so why do these texts perpetuate this myth? Marjorie Garber, in Shakespeare After All, argues that "Every age creates its own Shakespeare."13 I began thinking about recent conscious fictions of Shakespeare and his actors and asking why we have created these Shakespeares and why now?

6 In order to address this question, I considered the role participatory media now plays in shaping $21^{\text {st }}$ century, popular culture, Shakespeares. In many ways, the internet has become synonymous with popular culture; it is a tool used to create, disseminate and/ or critique popular culture texts. As noted by Henry Jenkins, Sam Ford and Joshua 
Green, in Spreadable Media, the spread of media texts today is a "mix of top-down and bottom-up" and the public are no longer "simply consumers of preconstructed messages but [are] people who are shaping, sharing, reframing and remixing media content." ${ }^{14}$ The television series Upstart Crow is an example of top-down use of social media as a promotional tool to appeal to younger audiences, releasing a video on Facebook targeted at UK students. In the video, David Mitchell's Shakespeare, introduced as "the greatest writer of all time," tells the students "it's absolutely not my futtocking fault that you have to study my plays" and "yes, my jokes aren't funny, but do you think your 'hilarious' memes will still raise a giggle in the $25^{\text {th }}$ century?"; he goes on to say "They're not even funny now if you ask me." ${ }^{15}$ As with the television series, the video uses language intended to attract a wide audience, while also including references designed to appeal to a smaller demographic, what Jostein Gripsrud terms "double-access" audiences. ${ }^{16}$ Gripsrud argues that a distinction between high and low culture still exists and only double-access audiences are able to appreciate both the high and low aspects of the texts. ${ }^{17}$ For example, in the first episode of Upstart Crow, Shakespeare tells his wife "I have a unique and timeless insight into the very heart of what it is to be human" and repeats the sentiment in the second episode with "Actually, understanding human nature is one of my big things." ${ }^{18} \mathrm{This}$ is also referenced in Doctor Who "The Shakespeare Code" when the Doctor describes Shakespeare as "The most human human there's ever been." ${ }^{19}$ These could be seen as references to Harold Bloom's Shakespeare: The Invention of the Human, which argues that "Our ideas as to what makes the self authentically human owe more to Shakespeare than ought to be possible." ${ }^{20}$ There would be few audience members who would make this connection, the writers have included the reference to allow those that do a moment of recognition.

7 Doctor Who "The Shakespeare Code" has many references included for double-access audiences. For example, following an exchange with Martha, Shakespeare then flirts with the Doctor, who responds with "Oh, 57 academics just punched the air," referencing the theory that Shakespeare was bi-sexual. ${ }^{21}$ Even the number 57, which appears to be rather specific, is targeted at select audience members. Sonnet 57 is dedicated to the fair youth, with whom Shakespeare was said to have been in love, and it focuses on time:

Being your slave, what should I do but tend

Upon the hours and times of your desire?

I have no precious time at all to spend,

nor services to do, till you require;

Nor dare I chide the world-without-end-hour

Whilst I, my sovereign, watch the clock for you ${ }^{22}$

8 In the television series, the Doctor travels through space and time. Those familiar with Shakespeare's sonnets would be able to make the connection between the number 57, sonnet 57, the fair youth and Shakespeare's supposed bisexuality. However, participatory media platforms have made it easier to become part of a double access audience. Any viewers of "The Shakespeare Code" curious about why the Doctor said 57 academics can search online and find hundreds of pages discussing the comment. ${ }^{23}$ Pages created by and for fans of Doctor Who provide access to information, which previously would have been more difficult to disseminate, and are examples of the "bottom-up" spread of media texts. ${ }^{24}$ By providing platforms to create and spread information, it could be argued that the internet has begun democratising high culture. 
9 Therefore, thinking back to the question of why these Shakespeares now, the conclusion I reached was that Bardolatry remains alive and well in the age of participatory media, although as memes require, its form has evolved. As Anna Blackwell argues in "Shakespearean Actors, Memes, Social Media and the Circulation of Shakespearean 'Value'," memes are "explicitly intertextual in nature: they invoke and sustain comparisons between different modes and media." ${ }^{25}$ It would be challenging to examine representations of Shakespeare and his actors today without also considering these different modes and mediums. Popular culture conscious fictions of Shakespeare operate as fictionalised accounts of the acting profession in Elizabethan and Jacobean London, but they draw on our modern expectations and attitudes. These transformations and replications give audiences a greater sense of ownership of Shakespeare, which allows him and his works to survive in the $21^{\text {st }}$ century. The remainder of this essay will explore the common tropes evident in recent popular culture texts that feature Shakespeare as a character along with his actors and argues that, through these examples, we can consider Shakespeare as meme.

\section{Shakespeare the Actor}

10 Although one of the earliest references we have to Shakespeare comes from Robert Greene's Groats-Worth of Wit, in which he calls him "an upstart Crow, beautified with our feathers" and accuses him of having a "Tygers hart wrapt in a Players hyde," conscious fictions of Shakespeare tend to focus on him as a writer/poet, rather than as an actor. ${ }^{26}$ While these representations may emphasise his fallibility in other areas, including acting, parenting, marriage and ethics, they largely do not call into question his genius in relation to writing; even a purported tendency towards plagiarism is not seen as a failure in genius. ${ }^{27}$ Some recent conscious fictions also repeat the biographical fallacy that Shakespeare was "a much better poet than player," first written in 1699 in James Wright's Historia Histrionica. ${ }^{28}$ In 1825 , Nicholas Rowe wrote that Shakespeare was distinguished "if not as an extraordinary actor, yet as an excellent writer." ${ }^{29}$ This was repeated by Sidney Lee in 1904, who claimed that Shakespeare "was never to win the laurels of a great actor." ${ }^{30}$ This trope is most evident in Something Rotten; during the song "God I Hate Shakespeare," Nick Bottom exclaims that he does not understand "how a mediocre actor / From a measly little town / Is suddenly the brightest jewel / In England's royal crown." ${ }^{31}$ Later, when Nick and Shakespeare meet, Shakespeare tells his adoring fans that "We should thank this man. He was the one who suggested I take up writing in the first place" to which Nick responds, "Because you're a shit actor." 32

11 However, there is no evidence from the era to suggest that Shakespeare was a bad actor. It is apparent that Shakespeare continued acting, even after he began writing. In 1603, Shakespeare was listed as an actor in a licence issued to the King's Men, he was also in a list of "players' who were given four yards of red cloth each for ceremonial apparel for the coronation of King James I" and was included in a cast list for a performance of Ben Jonson's Sejanus in the same year..$^{33}$ As John Paul Rollert has asserted, it is unlikely Shakespeare would have remained on the stage as long as he did, had he genuinely been a bad actor. ${ }^{34}$ This is an example of a cultural idea that has replicated across generations, repeated from a theatre history published in 1699 through to a Broadway musical theatre production in the $21^{\text {st }}$ century. It has given rise to internet forum discussions about the veracity of the claim, providing an outlet for 
those seeking more information about Shakespeare the actor. ${ }^{35}$ In this, we can see an example of Shakespeare as meme and the affordances of participatory media in facilitating both its spread and in questioning its authenticity.

\section{Early Modern Acting Aspirations}

12 A second trope commonly seen in the popular culture conscious fictions of Shakespeare and his actors is that acting was a profession to which others aspired. This is also predicated on $21^{\text {st }}$-century notions of the cultural cache attached Shakespearean actors, rather than Elizabethan and Jacobean attitudes. Anna Blackwell argues that Shakespearean actors today are "frequently coded as a representative of 'high' cultural values." ${ }^{36}$ In Something Rotten! it is clear that Shakespeare's actors are more highly regarded. This is evident when Nick Bottom's players sing about Shakespeare, taunting Bottom with "The man really knows how to write a bitchin' play / You wish you could pen one, we wish we were in one." ${ }^{{ }^{37}}$ The musical also features the character of Shylock, a Jewish moneylender who wants to finance the Bottom Brother's next play. His motivation is a love of the theatre, he tells Nick Bottom "what I really love ... is the theatre, I love it, I love it, I love it, I love it! I love the sounds, the smells, the roar of the crowd, the splat of the fruit against the actors. It's a temple to me, I tell you, a temple, my religion is theatre!" ${ }^{38}$ Shylock has no interest in being on the stage, however he offers to forgive Nick Bottom's overdue debts if he allows him to fund a production. This is an example of a parasocial interaction between a "fan" of the theatre and a poet/actor. ${ }^{39}$ The desire to create a relationship with those in the entertainment industry is not necessarily a new phenomenon, however the rise of participatory media, in particular platforms like Facebook, YouTube and Twitter, has allowed audiences greater access to their favourite stars and to creators of popular culture texts, such as writers, directors and showrunners. These platforms allow fans to "draw connections, interpret and engage" with the object of their fandom. ${ }^{40}$

Representations of ordinary men with theatrical aspirations are also prominent in Shakespeare in Love. A major plot point sees Philip Henslowe needing to replace Ned Alleyn and his regular players who are touring the countryside. To achieve this, Henslowe calls open auditions in a local pub and the film's audience are then shown a series of auditionees, all performing Christopher Marlowe's "Was this the face that launch'd a thousand ships" from Doctor Faustus. ${ }^{41}$ Henslowe insists on casting his tailor, who wants to be an actor and to whom he owes money. This tailor, who has a distinct stutter, is cast as the Prince and, in true Hollywood fashion, overcomes this impediment and delivers his lines perfectly on the day. The money-lender Fennyman is another example of a professional man with theatrical aspirations; a drunken Shakespeare casts him as the Apothecary in Romeo and Juliet and later in the film, we see flyers promoting the show featuring a prominent line at the bottom "with $\mathrm{Mr}$ Fennyman as the Apothecary." 42 These men are not looking to create parasocial relationships with the stars of the theatre, they are seeking to become stars themselves. Although Shakespeare in Love was released before social media platforms and the internet became ubiquitous, it was made at a time when reality television was becoming increasingly popular. Television programmes such as The Real World, Cops, Changing Rooms and Sylvania Waters purported to represent real people and provided participants with a modicum of fame, however fleeting it may have been. 
Modern conscious fictions of Shakespeare and his players also include women who want to act but are prevented by conventions and laws that do not permit women on the stage. In these representations there is a desire for an early form of feminism, a $21^{\text {st }}$-century assumption that intelligent women must have wanted to act. In Shakespeare in Love this drives the plot; the first time the audience sees Viola De Lesseps, she is at court, watching The Two Gentlemen of Verona and mouthing along to the lines. She bemoans the lack of women on the stage, complaining that "Stage love will never be true love, while the law of the land has our heroines played by pipsqueak boys in petticoats! [...] I would stay asleep my whole life if I could dream myself into a company of players." ${ }^{43}$ Viola auditions and is cast as Romeo, however she must hide her female body beneath bandages and male attire. In Upstart Crow, the character Kate is also a clever and well-educated woman who has theatrical aspirations. She is an innkeeper's daughter and, unlike Viola in Shakespeare in Love, lacks opportunity for social advancement. However, as her dream is to be an actor, she spends much of her time during the series trying to convince Shakespeare to allow her the opportunity to play his roles. The most common response to her request is that "girls can't act" and this is meant in two ways. The first meaning is that there was a law that prohibited women from performing professionally, which was not actually the case. While convention dictated only men acted professionally in England, there were instances of women being involved in the theatre in other ways. ${ }^{44}$ The second meaning is that "it takes a bloke" to act a woman, because "women aren't clever enough." ${ }^{45}$ Bottom explains to Kate the finer points of female impersonation, advising her that her movements would be better with "two half coconuts shoved down your bodice, except they wouldn't fit, would they? No room for falsies because of your realsies." ${ }^{46}$ This is later re-iterated by Shakespeare, who tells her "you can't be an actor, you're a girl. Where would you put the coconuts?" and then a third time from Kit Marlowe, who says "Women can't act obviously [...] where would you put the coconuts?"; even Kate herself asks "Where would I put the coconuts?" ${ }^{47}$ In a later episode, Shakespeare again tells Kate "The more I think about it, the more I see is that what is required to convincingly portray a woman onstage is not feminine understanding or girlish insights, it's a squeaky voice, pouty lips and a couple of half coconuts." ${ }^{18}$ Kate's theatrical aspirations become a running joke throughout the series and in the final episode of the first season, she is given the opportunity to pretend to be a male lawyer. However, while Kate is mostly able to convince those around her that she is male, she is ultimately outed by her choice of a salad for lunch. Richard Burbage tells her "We get one like you every fortnight, silly little girls, pretending to be boys, in the pathetic hope that they'll be as good at being girls as boys are." ${ }^{49}$ Burbage's line suggests that Kate's desire to act is nothing original and that crossdressing women, pretending to be male so that they can perform on the stage, is common.

There is, of course, no real evidence to suggest that women were disguising themselves in order to act on the pre-Restoration stage. Rather, the trope is based on a modern desire to position women as active agents in agitating for change on the Elizabethan/ Jacobean stage. Arguably, this desire arises out of the same impulses that gave rise to Fourth-wave feminism, which is "defined by its focus on technology" and uses digital mediums to communicate. ${ }^{50}$ Fourth-wave feminism seeks greater equality between the sexes and uses social media in particular to highlight injustices. When creating $21^{\text {st }}$ century popular culture representations of Shakespeare's actors, it is perhaps not surprising that these texts have included female characters wanting the opportunity to 
act in his plays. Retrospectively adding feminist characters into Shakespeare's social circle allows him to remain relevant today.

\section{Comedic Transvestism}

16 The third common trope seen in popular culture conscious fictions of Shakespeare and his actors is that men playing women's roles is meant to be funny. This is not to say the texts themselves are suggesting the early modern audiences would have found all men in women's roles funny. Although Shakespeare did explore comedy and crossdressing in plays like As You Like it, with conscious references to the boys playing the female roles, this was a deliberate choice for some roles and most of the boy players and male actors playing women would have been accepted as the character. Yet, recent texts like Upstart Crow, Something Rotten, Doctor Who "The Shakespeare Code" and Shakespeare in Love, feature at least one male actor who specialises in female characters and their scenes are often played for laughs. In Upstart Crow, Henry Condell is the actor who plays female parts and his dress, accessories and mannerisms are what have been traditionally coded within western society as feminine. His clothing, when not wearing a dress, is pink; he is more quietly spoken than Burbage and Kempe and acts in a jealous manner when he learns of Kate's aspirations for the stage. In the first episode, Condell is desperate to prove that he can still play young female roles and attempts to seduce a nobleman, who exclaims "she looks like a man in a dress." ${ }^{11}$ Doctor Who "The Shakespeare Code" shows Martha and the Doctor visiting the newly opened Globe and applauding enthusiastically at the end of a play; Martha asks the Doctor "And those are men dressed as women, yeah?' to which he replies "London never changes." ${ }^{52}$ In Something Rotten!, Robin is an actor who plays female roles and he is always shown wearing a dress. Early in the musical, Bottom's company are rehearsing and, when Robin runs on in a dress and asks "did I miss my cue," Nick demands to know what he is wearing, as it's not yet dress rehearsal. Robin replies "I thought it would help me get into character if I were to wear dresses, hang out in taverns and flirt with men. You know, for research." ${ }^{53}$ Finally, Shakespeare in Love also includes examples of comedy that is meant to come from transvestism; however, in the movie, the comedy comes from how convincing the actor is in female roles. When the production of Romeo and Juliet is betrayed by a young John Webster for having a woman in the cast, the Master of the Revels Tilney comes to the theatre to close down the play "For lewdness and unshamefacedness! For displaying a female on the public stage. ${ }^{54 "}$ He then pulls up Sam's dress, to expose his supposedly womanly parts. Webster tells him "Not him, her," pointing at Viola and Henslowe exclaims "He's a woman." ${ }^{55}$

What is most interesting about this particular trope is that, unlike the other two, it does not correlate with changing $21^{\text {st }}$-century attitudes facilitated by participatory media. The performance of gender has long been discussed and theorised, most notably by scholars such as Simone de Beauvoir and Judith Butler, who recognise that gender identity is not binary and that gender itself is constructed. ${ }^{56}$ Participatory media platforms provide spaces for discussion of gender and identity and allow users greater access to information and education. Yet, these popular culture texts continue to repeat the "joke" that men pretending to be women is funny. Butler addresses this in a discussion about the performance of drag, arguing that drag brings together "three contingent dimensions of significant corporeality: anatomical sex, gender identity and 
gender performance" and this creates a "dissonance" which "reveals the imitative structure of gender itself - as well as its contingency." 57 While audiences in Shakespeare's time would not have seen all drag performances as comedic, audiences today react to this dissonance with laughter. Transvestism as comedy is, itself, a meme that has been replicated and repeated in popular culture. It can be seen in the English pantomimes of the $19^{\text {th }}$ and $20^{\text {th }}$ centuries, American variety television programmes of the 1950s and 1960s, French talk shows from the late 1980s, and in popular culture texts that feature Shakespeare's actors.

\section{Conclusion}

These conscious fictions of Shakespeare and his actors in popular culture are meant, according to Douglas Lanier, to "speak to collective aspirations, fears, pleasures, identities, and experiences of disempowerment ... In its search for Shakespeare the man, pop has found the hall of mirrors in the funhouse of authorship." ${ }^{58}$ It is undeniable that each generation "creates its own Shakespeare" and throughout the ages we can see that the generations have recreated him in their own image. Our Shakespeare, in the era of participatory and social media, is a flawed genius whose company is apparently made up of amateurs and women in disguise. These representations speak to modern audiences about themes such as: anti-Semitism, class struggles, toxic masculinity, and feminism. The messages are boosted by the cultural capital that comes from Shakespeare and they proliferate through new media forms. This "brave new world" also presents opportunities for Shakespeare to remain relevant to new generations, using his character "powerfully in the context of current concerns." 59

\section{NOTES}

1. Karey Kirkpatrick and Wayne Kirkpatrick, "Hard to be the Bard", Something Rotten! Written by Karey Kirkpatrick, Wayne Kirkpatrick and John O’Farrell, (Compact Disc), 2015.

2. Jennifer Holl, "YouShakespeare: Shakespearean Celebrity 2.0", Shakespeare/Not Shakespeare, ed. Christy Desmet, Natalie Loper and Jim Casey, Cham, Palgrave Macmillan, 203-219, p. 215.

3. One of the examples Dawkins gives is whistling a tune, which is then "caught" by others and carried on; it is something that is copied from one person to another, from one generation to another. While genes are exactly copied, memes are not, they cannot be as they become altered when they pass through different generations. By "generation", Dawkins is not necessarily talking about time, but rather iterations. Richard Dawkins, "Memes", Oxford Union, 2014 (accessible online at https://www.youtube.com/watch?v=4BVpEoQ4T2M, last accessed 3 January, 2020)

4. Mike Ingham, "Following the dream/passing the meme: Shakespeare in 'translation", Studies in Theatre and Performance 28.2, 2008, 111-126, p. 112.

5. The term text is used in this essay as "Pop culture texts encompass both print and nonprint formats including film, television, music, and video games, as well as fiction and nonfiction 
books," Botzakis as cited in Leigh A. Hall, "How Popular Culture Texts Inform and Shape Students' Discussions of Social Studies Texts", Journal of Adolescent \& Adult Literacy 55.4, 2011, 296-305, p. 296.

6. Jennifer Moss Waghorn, “The Bard is Dead, Long Live the Bard: Celebrations of Shakespeare's 'Corpse' and 'Corpus' in 2016”, Shakespeare 14.2, 2018, 275-290, p. 275.

7. Brian Cummings, “Zombie Shakespeare”, Palgrave Communications 2, 2016, 1-5, p. 1 (accessible online at: https://www.nature.com/articles/palcomms201663\#citeas, last accessed 3 May 2020)

8. Ronan Hatfull, “'Shakespeare in the Park?': William Shakespeare and the Marvel Cinematic Universe", Foundation 48.134, 2019, 45-57, p. 47.

9. Maurice J. O'Sullivan, “Shakespeare's Other Lives", Shakespeare Quarterly 38.2, 1987, 133-153, p. 133.

10. The Shakespeare Code", Doctor Who, written by Gareth Roberts, directed by Charles Palmer, April, 2007, BBC.

11. Kirkpatrick \& Kirkpatrick, op. cit.

12. Kelly Jones, “'It's all a bit Harry Potter': The Bard, the Doctor and the cultural TARDIS in Doctor Who: The Shakespeare Code", The Journal of Popular Culture 48.2, 2015, 240-250, p. 241.

13. Marjorie Garber, Shakespeare After All, Woodston, Anchor Books, 2005, p. 3.

14. Henry Jenkins, Sam Ford, Joshua Green, Spreadable Media: Creating Value and Meaning in a Networked Culture, New York, New York University Press, 2013, p. 2-3.

15. BBC Comedy, "Upstart Crow - Message from the greatest writer of all time", posted 16 August, 2018 (accessible online at: https://www.facebook.com/bbccomedy/videos/vb. 130593816777/314324615781969/?type=2\&theater, last accessed 3 May 2020).

16. Joseph Gripsrud, “'High culture' revisited”, Cultural Studies 3.2, 2006, 194-207, p. 199.

17. Ibid.

18. “Star Crossed Lovers", Upstart Crow, written by Ben Elton, directed by Matt Lipsey, May, 2016, BBC; “The Play's the Thing”, written by Ben Elton, directed by Matt Lipsey, May, 2016, BBC.

19. "The Shakespeare Code", op. cit.

20. Harold Bloom, Shakespeare and the Invention of the Human, London, Fourth Estate, 1998, p. 17.

21. "The Shakespeare Code", op. cit.

22. William Shakespeare, The Norton Shakespeare, eds. Stephen Greenblatt, Walter Cohen, Jean E. Howard and Katharine Eisaman Maus, $2^{\text {nd }}$ ed., 2008, New York, W. W. Norton and Company, p. 1965.

23. See "The 57 in The Shakespeare Code" https://www.reddit.com/r/doctorwho/comments/ 3xynvd/the_57_in_the_shakespeare_code/, “Sonnet 57" https:// thewatsonbeekeepers.tumblr.com/post/93953127344/sonnet-57 and "Recap / Doctor Who S29 E2 "The Shakespeare Code"” https://tvtropes.org/pmwiki/pmwiki.php/Recap/ DoctorWhoS29E2TheShakespeareCode as examples

24. Jenkins, Ford \& Green, op. cit., loc. cit..

25. Anna Blackwell, "Chapter 5: Shakespearean actors, memes, social media and the circulation of Shakespearean 'value"', Shakespeare's Cultural Capital: His Economic Impact from the Sixteenth to the Twenty First Century, eds. Dominic Shellard and Siobhan Keenan, London, Palgrave Macmillan, 2016, 77-98, p. 91.

26. Robert Greene, Greens Groats-Worth of Witt: Bought with a Million of Repentance, London, J. Wolfe and J. Danter, 1592, STC 12245, sig. F1v-F2r.

27. Even Shakespeare in Love, which shows Shakespeare as suffering from writer's block at the start of the movie, still represents him as a tortured genius, waiting for the right muse.

28. James Wright, Historia Histrionica: An Historical Account of the English Stage, London, G. Croom, 1699, Wing W3695, p. 4.

29. Nicholas Rowe, The Dramatic Works of William Shakespeare, London, printed for Mason and Co by Jones and Co, 1823, p. 5. 
30. Sidney Lee, Great Englishmen of the Sixteenth Century [1904], Hamburg, Severus, 2013, p. 266.

31. Kirkpatrick \& Kirkpatrick, “God, I Hate Shakespeare”, op. cit.

32. Karey Kirkpatrick and John O'Farrell, Something Rotten!, New York, St James Theatre (Live Theatre), 2015.

33. John Doherty, The Ignorance of Shakespeare, Houston, Strategic Books, 2009, p. 224.

34. John Paul Rollert, "Shakespeare and the Theater of the Self", Raritan 3.4, 2015, 108-117, p. 110-111.

35. See "How good an actor was Shakespeare known to be?" https://www.quora.com/How-goodan-actor-was-Shakespeare-known-to-be and "Shakespeare the Actor and Playwright" http:// www.shakespeare-online.com/biography/shakespeareactor.html as examples.

36. Blackwell, op. cit. p. 79.

37. Kirkpatrick \& Kirkpatrick, “God, I Hate Shakespeare”, op. cit.

38. Kirkpatrick \& O’Farrell, op. cit.

39. A parasocial interaction happens "between audience members and media personae and is generally characterised by feelings of closeness," Jonathan Cohen, "Mediated relationships and social life: Current research on fandom, parasocial relationships, and identification", Media and Social Life, eds. Mary Beth Oliver and Arthur A. Raney, New York, Routledge, 2014, 142-156, p. 144.

40. Blackwell, op. cit. p. 91

41. Christopher Marlowe, Doctor Faustus, ed. John D. Jump, Manchester, Manchester University Press, 1976, sc. 18.99 .

42. Shakespeare in Love, op. cit.

43. Ibid.

44. Clare McManus, "Women and English Renaissance drama: Making and un-making the 'allmale stage"', Literature Compass 4.3, 2007, 784-796.

45. “The Play's the Thing”, loc. cit.

46. Ibid.

47. Ibid.

48. "Love is Not Love", Upstart Crow, written by Ben Elton, directed by Matt Lipsey, May, 2016, $\mathrm{BBC}$.

49. "The Quality of Mercy", Upstart Crow, written by Ben Elton, directed by Matt Lipsey, June, 2016, BBC.

50. Henrike Knappe and Sabine Lang, "Between whisper and voice: Online women's movement outreach in the UK and Germany”, European Journal of Women's Studies 21.4, 2014, 361-381, p. 364 and p. 381.

51. "Star Crossed Lovers", op. cit.

52. Shakespeare in Love, op. cit.

53. Kirkpatrick \& John O'Farrell, op. cit.

54. Shakespeare in Love, op. cit.

55. Ibid.

56. Simone du Beauvoir, The Second Sex, trans. E.M. Parshley, New York, Vintage, 1997, p. 295; Judith Butler, Gender Trouble: Feminism and the Subversion of Identity, Abingdon, Routledge, 2014, p. 12.

57. Butler, op. cit., p. 175.

58. Douglas Lanier, Shakespeare and Modern Popular Culture, New York, Oxford University Press, 2002, p. 142.

59. Ivo Kamps, "Alas poor Shakespeare! I knew him well”, Shakespeare and Appropriation, eds. Christy Desmet and Robert Sawyer, London, Routledge, 1999, 15-32, p. 27. 


\section{ABSTRACTS}

William Shakespeare, as a writer and actor, has recently become a popular fictional character in different forms of entertainment. Conscious fictions of Shakespeare in popular culture have proliferated since the rise of participatory media. Shakespeare on Twitter (@Shakespeare) has more than 40,000 followers, while William Shakespeare (@WilliamshakespeareAuthor) on Facebook has over 16 million "likes". In this, we can see a postmodern need to reshape Shakespeare in our own image, while simultaneously drawing on his cultural capital to either promote or challenge his work as "high" art. There have also been recent popular culture representations of Shakespeare's actors. These representations operate as fictionalised accounts of the acting profession in Elizabethan/Jacobean England, drawing on our modern expectations and attitudes to appeal to contemporary audiences. This essay will examine modern representations of Shakespearean actors from the past twenty-five years, including the film Shakespeare in Love, musical Something Rotten and television series Upstart Crow. It will explore the existing frameworks and theoretical approaches used when discussing popular culture Shakespeare. This essay will also consider the fictionalised accounts of the acting companies as depicted in the texts. In doing so, it will examine the authenticity of these portrayals against what is known of actors and the acting profession in the Shakespearean era and address the desires represented by these depictions today. The essay will explore three common tropes evident in popular culture representations of Shakespeare's actors. First, Shakespeare was a bad actor. Second, acting was a profession that others aspired to; this includes amateurs wanting to be professional and women wanting to perform. Third, males playing female characters was funny; the representations of theatrical transvestism in these popular culture texts are typically played for comedy today. Overall, this essay examines how Shakespeare's actors have been represented online, on screens and in theatres in the age of participatory media.

En tant qu'écrivain et acteur, William Shakespeare est récemment devenu un personnage fictif populaire dans différentes formes de divertissement. Les métafictions de Shakespeare se sont étendues dans la culture populaire depuis l'essor des médias participatifs. Le compte Twitter de Shakespeare (@Shakespeare) est suivi par plus de 40000 personnes, tandis que son compte Facebook (@WilliamshakespeareAuthor) a dépassé les 16 millions de "Likes". On peut voir ici un besoin de refaçonner Shakespeare à notre image, tout en jouant sur son capital culturel, soit pour promouvoir, soit pour critiquer le caractère élitiste de ses œuvres. Il y a également eu des représentations récentes des acteurs shakespeariens dans la culture populaire. Celles-ci fonctionnent comme des représentations fictionnelles de la profession d'acteur dans l'Angleterre élisabéthaine / jacobéenne, qui utilisent nos attentes et nos attitudes modernes pour intéresser le public d'aujourd'hui. Cet article analysera les représentations des acteurs shakespeariens produites au cours des vingt-cinq dernières années, y compris dans le film Shakespeare in Love, la comédie musicale Something Rotten et le programme de télévision Upstart Crow. Il examinera la façon dont les compagnies sont décrites. De ce fait, on pourra évaluer l'authenticité de ces représentations par rapport à ce que l'on sait des acteurs et de leur profession d'acteur du temps de Shakespeare et analyser les désirs sous-jacents qu'elles révèlent. Cet article analysera trois des tropes les plus les plus courants associés aux acteurs shakespeariens la culture populaire. Premièrement, Shakespeare était un mauvais acteur. Deuxièmement, être acteur était un métier désirable (les amateurs voulaient devenir professionnels et les femmes voulaient être sur scène). Troisièmement, il était comique de voir des hommes jouer des rôles de femmes; aujourd'hui, les représentations du travestissement dans la culture populaire sont généralement source de comédie. Sur un plan plus général, cet article analyse la façon dont les acteurs Shakespeariens 
sont représentés sur internet, sur les petits et grands écrans ainsi qu'au théâtre à l'ère des médias participatifs.

INDEX

Keywords: Popular culture Shakespeare, conscious fictions, double-access texts, representation, Shakespeare in Love, Something Rotten, Upstart Crow

Mots-clés: culture populaire de Shakespeare, les métafictions, représentations, Shakespeare in Love, Something Rotten, Upstart Crow.

\section{AUTHOR}

MELISSA MERCHANT

Murdoch University 